\title{
Mangrove Forest Ecosystem Utilization And Depletion: Implication For Occupational Changes In Calabar South, Nigeria
}

By

Okpiliya F.I ${ }^{1}$, Effiong E.B ${ }^{1}$, Imoke Eni ${ }^{1}$, Eja, Eja I²,

\begin{abstract}
The aim of this study was to examine the various ways in which mangrove forest ecosystem is being utilized and depleted and the implications for occupational changes in the area. Five communities based on observation that are actively involved in the mangrove exploitation were sampled for the study. Using the Yaro Yamen (1980) formula, the sample size of 400 was determined. Based on this, 400 copies of questionnaires whose content bothers on utilization of mangrove, income generated and occupation of the sampled communities was developed and administered. In order to determine the mangrove ecosystem depletion rate, the change intensity index was used. A multi-temporal image data of the mangrove vegetation covering areas overtime was acquired and processed. This include a Topo sheet derived from an aerial photo of 1970, land imagery 1970-2011 in a GIS environment (Arc GIS 9.3).
\end{abstract}

Key words: Mangrove, Ecosystem, Forest, Depletion, Occupation

\section{Introduction}

According to Ukpong (2009), mangrove plants are facultative halophytes; any of about 55 species of trees, shrubs, ferns and palm are found in the tropics and sub-tropics on protected river banks and along coastlines. Mangrove occurs where the average temperature of the coldest month is greater than $20^{\circ} \mathrm{C}$ and the seasonal range does not exceed $5^{\circ} \mathrm{C}$. The plants are unusually adapted to anaerobic conditions of both salt and freshwater environments. They cover an estimated distance of $180,000 \mathrm{~km}^{2}$ worldwide and are most luxuriant around the mouth of large rivers and sheltered bays. The mangrove roots not extend through water and into bottom sediments while the leaves and branches raise several meters above high water level. The roots trap sediment in the brackish water environment and often have a filtering effect by removing solutes from the water. The trees and shrubs get the oxygen they require in the oxygen deficient silt bed through roots which protrude above the water at low tide and funnel the oxygen down to the rest of their silt-covered roots.

${ }^{1}$ Department of Geography and Environmental Science, University of Calabar, Nigeria

${ }^{2}$ Department of Urban and Regional planning, Cross River State University of Technology,

Calabar. Nigeria 
The importance of mangrove generally cannot be over emphasized. Mangrove trees remained the most efficient photo synthesizers than almost any other plant, mangrove forms a life support system for much of the tropical world's coastal marine life (Russell 1996). Equally, Quarto (2001) in a quarterly report of mangrove Action project showed statistically that three-fourth of the tropical world's fisheries depend upon mangrove forest. Mangroves also serve as fish nurseries and breeding grounds for finfish, crabs, shrimps, Mollusks, and other sea life. Vast quantities of fallen leaf and branch detritus provide food for countless tiny marine creatures at the bottom of the global ocean food chain. They are also essential habitats for many endangered species such as manatees, American alligators, Bengal tigers and dark headed cuckoo. They constitute prime nesting sites for multitudes of shore birds, rare and migratory birds, crab-eating raccoons, proboscis monkeys, fishing cats, and jaquars. Monitor lizards and mudskipper fish also utilize mangrove wetlands as habitat and source of food. Again, Chan (1984) in the study of Human habitation and traditional uses of the mangrove ecosystem in peninsular Malaysia revealed that mangroves maintain water quality being that they are effective at filtering inshore pollutants and protecting fresh water sources from salt water intrusion. He further stressed that the mangrove ecosystem remain a source of valuable resources essential for the livelihood and survival of indigenous coastal people, which may include: sea food; fuel wood, construction materials, medicines, soaps, honey, oils, and tannins. Mangrove ecosystems are the greatest and often the only protein sources for millions of traditional villagers worldwide.

In a related development, Mantra (1986) in the study of socio-economic problems of the Kampung Laut community in central Java also show that mangrove serves in the protection of shorelines from erosion and flood regulation, violent storms and hurricanes.

\section{Objectives}

1 To examine the various ways in which mangroves are utilized.

2 To determine the income generated from the sale of mangroves in the area

3 To examine the Occupational changes that have taken place in the area as a result of mangrove forest depletion

\section{Study Area}

Calabar South Local Government is the study area. It is located along the Nigeria-Cameroon coast between Latitude $4^{0} \quad 55^{\prime} \mathrm{N}$ and longitude $8^{0} 16^{\prime} \mathrm{E}$ being part of the Calabar mangrove Estuary under West African mangrove sub formation (Ukpong 1995). Locally, it is bounded to the north, east and west by 
Calabar Municipality and Odukpani Local Government Areas respectively. It is bounded to the south east by Akpabuyo L.G.A.

The area is flanked on its eastern and western borders by two rivers, the Great Kwa and Calabar River respectively and to the south, by the Atlantic Ocean.

The climate of the area is humid tropical although rainfall occurs throughout the year. The place experiences double maxima, rainfall regime in July and September $(1880 \mathrm{~mm})$, the lowest rainfall values of $240 \mathrm{~mm}$ occur from December to February (Met; serv. 1980). The temperature is uniformly high with a maximum of $30^{\circ} \mathrm{C}$ and minimum of $23^{\circ} \mathrm{C}$ (NMS 1980). The area has a high relative humidity usually between $80 \%$ and $100 \%$ and vapour pressure in the air averaged 29 millibars throughout the year. High salinity $(3.8 \pm 0.4 \%)$ is limited to the dry season while lower salinity $(0.5 \pm 0.6 \%)$ occurs in the rainy season (Ukpong1995). Tidal amplitude in the estuary ranges from $2.01 \mathrm{~m}$ at spring tides to $1.07 \mathrm{~m}$ at neap tides (Nigerian Navy 1986).

The present settlement starts from the mouth of the estuarine coastline and projects to the hinterland and it's growth to the south is limited by the mangrove swamps. Fallow land is available only eastwards up to the Great Kwa River and northward. The area is an interflurial settlement, typical in this part of the country built on high area between two adjacent rivers. This locational advantage permits easy access especially through waterways for intending migrants who are mostly fishermen and traders in wood and craft items to the area. However, the swamp as a whole varies by less than 1 in 500 metres in elevation except on the upland forest ecotone where abandoned levees may exceed 1 in 500metres(Ukpong 1995).

The settlement pattern following the order above takes the linear shape except within and extending $20 \mathrm{~km}$ of the mangrove forest area to the Atlantic ocean, some clustered fishing settlement pattern are identified otherwise known as Ine (Fishing port). The presence of these fishing settlements in the area provided and facilitated easy access into the mangrove forest for rapid exploitation of its resources leading to increased depletion of the ecosystem.

Geologically, the area is composed of tertiary sandy deposits of fluviomarine origin. These are overlain by quaternary silty and clayey alluvium eroded from massive pre-Cambrian rocks of Oban hills in the outskirts. This characteristics poorly consolidated, non cohesive and porous rock formation permits large accumulation of water through constant and occasional flooding of the ecological zone. Floodwater recession or tidal retreat permits deposition of alluvial fans and levees quite supportive of plant growth. It accounts for occupational engagement in market gardening among dwellers. The soils are sandy; light hued in some location, but clayey, muddy, dark grey in colour, water logged and boggy. However, saline mangrove soils, developed on mud, sand or 
peat at the mouths of estuaries inundated by tropical tide water's (Ukpong1995).But more acid soils is identified to be associated in the zonation of Nypa fructican, Rhizophora species dominance (Ukpong 1995).

The predominant vegetation type is mangrove. The mangrove flora consists of trees and shrubs of few general varying species. The common genus is Rhizophora with three: $R$ racemosa, $R$ harisonii and $R$. mangle. The dominant feature of mangrove is the stilt roots of Rhizophora species. Associated with these species are Avicennia africana and Lagunculeria racemosa. There are also palms, Prodococcus bateri, Ancistrophyllum opacum and the gregarious and aggressive Nypa frutican. Salt marshes and sea grasses interact with the mangrove forest to support the entire coastal zone. Hence, because of its status of composition and structure it is known to be part of the most complex vegetation which is the northernmost limits of the Mangrove growth in the Cross River estuary (Ukpong 1995)

This complex plant community of wetland origin formed an ecological niche for reptiles, monkeys, birds, fishes, shrimps, mollusks, and other wildlife. Thus, it is often harvested for wood, fuelwood, tannin, leaves, fibers and dyes. Mangrove environment in particular is important for inland fisheries, serving as highly productive habitat for shell and finfish. These inform the migration of fishermen from Delta, Akwa Ibom and Akpabuyo to settle and take advantage of the rich supply at this point (Nest 1991).

Its estimated population in 2007 stands at 191,515 (NPC 2006); Inmigration has formed the major source of its population growth. The immigrant communities include Ibibio, Oron, Ibo, Ijaw, Anang, Urhobo, and other tribes within and outside Nigeria. Despite the ethnic intermix, a fraction of indigenous population mostly of the Efiks/Efut extraction are found in the locality.

This wave of migration brought along changing perception of interaction with the environment. This scenario contributed immensely in the remaking of the greater part of the mangrove ecosystem.

The rural people engaged in artisan fishing and the cultivation of vegetables, cassava and maize at commercial and subsistence level. Fishing is done using small nets to catch even fingerlings. Shrimp farming is also in vogue. It involves clearing/cutting down the available mangrove forest or aquatic fauna for making ponds. Logging and lumbering of fuel wood for charcoal Production sales and also for timber are common practices. The fish species are Ibat/Ekpai (Ethmalosa fimbrata). The bonga and flat Cameroon Sardine (S. Cammeronesis). Commercial shrimps and prawns found here are: Pink shrimp (Penacus duorarum), salt water prawns (Newmatopalaema spp) among others.

Economic wood species harvested are; mangrove, Achi gum (Oxystigma $s p p$ ), Owen (Mitragyna spp), Camwood (Pterocarpus spp), Mkpenek (Uapaca spp) and so on (Fayemi et al 2005). 


\section{Methodology}

Five communities that are known to be actively engaged in mangrove exploitation were used for this study- Anantigha, Cobham/Duke Town, Efut Obufa Esuk, Henshaw Town and Mbukpa Akani Esuk Orok.

The study sample size was determined by statistical calculations using the Yaro Yamen (1980) formula, which is given as:

$\left.\mathrm{n}=\mathrm{N} /[1+\mathrm{N} 0.05)^{2}\right]$

Where:

$$
\begin{aligned}
& \mathrm{n}=\text { Sample size } \\
& \mathrm{N}=\text { Sampled population } \\
& \mathrm{e}=\text { Level of precision or confidence level } \\
& \quad \text { at } 0.05 \text { significance }
\end{aligned}
$$

Hence:

$$
\begin{gathered}
\mathrm{n}=68355 /\left[1+68355(0.05)^{2}\right] \\
\mathrm{n}=400.00
\end{gathered}
$$

Table 1: Sampled Communities, and Population Sizes

\begin{tabular}{|l|l|c|c|}
\hline S/N & \multicolumn{1}{|c|}{ Communities } & Population 2008 & \multicolumn{1}{|c|}{$\begin{array}{c}\text { Proportion of } \\
\text { Sample size for } \\
\text { analysis }\end{array}$} \\
\hline 1. & Anantigha & 20,574 & 120 \\
\hline 2. & $\begin{array}{l}\text { Duke/Cobham Town } \\
\text { (Combined) }\end{array}$ & 13,460 & 79 \\
\hline 3. & Efut Obufa Esuk (Edibe- & 3,801 & 22 \\
\hline 4. & $\begin{array}{l}\text { Henshaw Town } \\
\text { Edibe inclusive) }\end{array}$ & 5,813 & 34 \\
\hline 5. & Mbukpa/Akani Esuk Orok & 24,707 & 400 \\
\hline
\end{tabular}

Source: Nat., population comm. (1991)/ Author's Field Report (2011)

Arising from this, 400 copies of questionnaire were distributed to the households. The content of the questionnaire included information on demographic characteristics, occupation, income as well as forms of utilization of the mangrove ecosystem in the area.

In order to determine the rate of mangrove depletion, multi-temporal image data of the mangrove vegetation covering areas overtime was acquired and processed which include a Topo sheet (197) derived from an areal Photo of 1970, 
land imagery 1970-2011 at 30m resolution. These data sets ware geo-referenced into a common framework in a GIS environment (Arc.GIS 9.3). Hence the area covered by mangrove and other land were produced. The mangrove ecosystem change rate or depletion was analyzed using the change intensity index was used. It has the form;

$$
\mathrm{T}_{\mathrm{i}}=\left(\mathrm{U}_{\mathrm{bi}} \mathrm{U}_{\mathrm{ai}}\right) / \beta * 100,(\mathrm{i}=1,2,3---\mathrm{n})
$$

Where, Ti denotes the intensity of the $i$ ' the land use type changes in the study period, Uai denotes the i'th land use type area at the ending $\beta$ denotes the total areas of Study at the ending.

\subsection{Utilization of Mangrove Wood}

As seen in table 2, 25 respondents (representing 6.25\%) utilize mangrove for cooking various food in the area. In this part of the country it is a common practice to see old women and young girls cooking with firewood derived from mangrove trees as preferred to Kerosene and gas. Observations from the field revealed that food tastes more when cooked with wood than other sources. Hence the continuous exploitation of mangrove for fuelwood in the area. Also, 20 respondents (representing 5\%) use mangrove for fish farming. 8 respondents $(2 \%)$ make use of mangrove for construction and building of houses, 4 respondents $(1 \%)$ use mangrove for agriculture purposes i.e. staking of yams and vegetables. A great percentage of the respondents (290) representing 72.5\% attested that mangrove is used in Bakery industry as energy source. It is an established fact that the bakery of bread requires huge source of energy which may not be provided for by continental energy sources which in most cases is costly. In this case, mangrove wood becomes the most readily source of energy for the bakers. Mangrove is also used in the area for charcoal production and for medicinal purposes as 50 respondents $(12.5 \%)$ and 3 respondents $(0.75 \%)$ respondents attested to this fact respectively.

Table 2: Forms of Utilization of Mangrove in the Study Area.

\begin{tabular}{|l|l|l|l|}
\hline S/no & Uses of Mangrove & Frequency of response & \% response \\
\hline 1 & Domestic cooking & 25 & 6.25 \\
\hline 2 & Fish smoking & 20 & 5 \\
\hline 3 & Building/construction & 8 & 2 \\
\hline 4 & Agriculture (staking Sticks) & 4 & 1 \\
\hline 5 & $\begin{array}{l}\text { Commercial bakery production (energy } \\
\text { source) }\end{array}$ & 290 & 72.5 \\
\hline 6 & Charcoal production & 50 & 12.5 \\
\hline 7 & Medical & 3 & 0.75 \\
\hline Total & & 400 & 100 \\
\hline
\end{tabular}

Source: Author's Field Survey, 2011. 


\subsection{Income Generated from Mangrove Wood Extraction in the Study Area Over the Years}

Income remained a major drive for the continuous extraction of mangrove wood in Calabar South. From table 3, it is observed that from the period of 1991 - 2011 (21 yrs), a total of N13, 633,140 and N27, 591120 has been generated as revenue to government and income for the people respectively, from cutting a total of 130, 724 trees of mangrove trees (pole and merchantable sizes). It is to be emphasized here too that both government and the people are beneficiaries in the mangrove exploitation.

Furthermore, the result revealed that nearly 50 per cent gain realized as individual income annually is based on tariff rate/tree purchased by the people. Thus, this explains income as a force (drive) which has made people to deplete mangrove arising from demand for fuel wood, and timber for construction/building including canoes and as a source of livelihood. On the other hand, the result further shows that income derived is based on the number of trees cut annually not on the measure of volume of wood cut. This is a lost to people and government because there is no awareness as well as regulatory and monitoring mechanism on the consumption and utilization of mangrove wood in the area based on the volume cut. The implication here is that the extractors will continue to cut more trees because their measure of sales is based on the number of trees cut.

\section{Mangrove Forest Depletion and Occupational Changes}

The result in table (4) show the area changes over the years, of mangrove forest (depletion). The result revealed that the rate of mangrove change (depletion) per year in the study period (1970-1991) was $0.145 \mathrm{~km} 2$ which represent $2.66 \%$ of the area change while in 1991-2011 there was a tremendous increase (rapidity) in the rate of change indicating that each year within this period $1.69 \mathrm{~km}^{2}$ of mangrove was being depleted representing $31.12 \%$ of the entire area changed whose competitive rivalry in land cover replacement was Nypa palm. Hence, any minus (change) in mangrove cover is likely to be a plus to Nypa palm first as colonizers. Therefore judging from the result in the two time period of study 1970-1991, 1991-2011, the differences in the percentage of area change $2.66 \%$ and $31.12 \%$ respectively, denotes a clearer result that the changes(loss) in the mangrove forest coverage of Calabar south has been progressive. 
Table 3: Income Generated From Mangrove Wood Extracted in the Study Area Over the Years

\begin{tabular}{|c|c|c|c|c|c|c|c|c|}
\hline $\mathrm{S} / \mathbf{N}$ & $\begin{array}{c}\text { Year of } \\
\text { Extraction }\end{array}$ & $\begin{array}{c}\text { No. of Trees } \\
\text { Extracted } \\
\text { (merchantible/ } \\
\text { poles) }\end{array}$ & $\begin{array}{c}\text { Tarrif cost } \\
\text { price } \\
\text { (merchantible } \\
\text { tree and pole) }\end{array}$ & $\begin{array}{c}\text { Annual } \\
\text { total } \\
\text { sales } \\
\text { based on } \\
\text { tariff rate } \\
\text { (N) }\end{array}$ & $\begin{array}{c}\text { Retail } \\
\text { unit } \\
\text { price } \\
\text { (Logs } \\
350 \mathrm{~cm} \\
\text { each) } \\
\text { pole } \\
\text { (N) }\end{array}$ & $\begin{array}{c}\text { Total } \\
\text { Annual } \\
\text { sales } \\
\text { income } \\
\text { Derived } \\
\text { (N) }\end{array}$ & $\begin{array}{c}\text { Sales } \\
\text { Difference } \\
\text { b/w } \\
\text { Annual } \\
\text { sales on } \\
\text { tarriff rate } \\
\text { \& retail } \\
\text { price (A) }\end{array}$ & $\%$ \\
\hline \multirow[t]{4}{*}{ 1) } & 1991 & & & & & & & \\
\hline & $\mathrm{M}$ & 152 & 1500 & 228,000 & 1800 & 273600 & & \\
\hline & $\mathrm{P}$ & 3640 & 10 & 36400 & 70 & 254800 & & \\
\hline & $\mathbf{T}$ & 3792 & & 264400 & & 528,400 & 264000 & 49.96 \\
\hline \multirow[t]{4}{*}{ 2) } & 1992 & & & & & & & \\
\hline & $\mathrm{M}$ & 180 & 1500 & 270,000 & 1800 & 324000 & & \\
\hline & $\mathrm{P}$ & 4528 & 10 & 45280 & 70 & 316960 & & \\
\hline & $T$ & 4708 & & 315,280 & & 640960 & 325680 & 50.81 \\
\hline \multirow[t]{4}{*}{ 3) } & 1993 & & & & & & & \\
\hline & $\mathrm{M}$ & 183 & 1500 & 274,500 & 1800 & 329400 & & \\
\hline & $\mathrm{P}$ & 4550 & 10 & 45,500 & 70 & 318500 & & \\
\hline & $\mathbf{T}$ & 4733 & & 320,000 & & 647900 & 327900 & 50.61 \\
\hline \multirow[t]{4}{*}{ 4) } & 1994 & & & & & & & \\
\hline & $\mathrm{M}$ & 178 & 1500 & 267,000 & 1800 & 320400 & & \\
\hline & $\mathrm{P}$ & 4582 & 10 & 45,820 & 70 & 320740 & & \\
\hline & $T$ & 4760 & & 312,820 & & 641140 & 328320 & 51.21 \\
\hline \multirow[t]{4}{*}{ 5) } & 1995 & & & & & & & \\
\hline & $\mathrm{M}$ & 185 & 1500 & 277,500 & 1800 & 333000 & & \\
\hline & $\mathrm{P}$ & 4666 & 10 & 46,660 & 70 & 326620 & & \\
\hline & $T$ & 4851 & & 324160 & & 659620 & 335460 & 50.86 \\
\hline \multirow[t]{4}{*}{ 6) } & 1996 & & & & & & & \\
\hline & $\mathrm{M}$ & 190 & 1500 & 285,000 & 1800 & 342000 & & \\
\hline & $\mathrm{P}$ & 4702 & 10 & 47,020 & 70 & 329140 & & \\
\hline & $T$ & 4892 & & 332,020 & & 671140 & 339120 & 50.53 \\
\hline \multirow[t]{4}{*}{ 7) } & 1997 & & & & & & & \\
\hline & $\mathrm{M}$ & 192 & 1500 & 288,000 & 1800 & 345600 & & \\
\hline & $\mathrm{P}$ & 4803 & 10 & 48,030 & 70 & 336210 & & \\
\hline & $T$ & 4995 & & 336,030 & & 681810 & 345780 & 50.72 \\
\hline \multirow[t]{4}{*}{ 8) } & 1998 & & & & & & & \\
\hline & $\mathrm{M}$ & 198 & 1500 & 297,000 & 1800 & 356400 & & \\
\hline & $\mathrm{P}$ & 4990 & 10 & 49,900 & 70 & 349300 & & \\
\hline & $T$ & 5188 & & 346900 & & 705700 & 358,800 & \\
\hline \multirow[t]{4}{*}{ 9) } & 1999 & & & & & & & \\
\hline & $\mathrm{M}$ & 200 & 1500 & 300,000 & 1800 & 360000 & & \\
\hline & $\mathrm{P}$ & 5010 & 10 & 50,100 & 70 & 350700 & & \\
\hline & $T$ & 5210 & & 350,100 & & 710700 & 360,600 & 50.74 \\
\hline \multirow[t]{4}{*}{ 10) } & 2000 & & & & & & & \\
\hline & $\mathrm{M}$ & 250 & 1500 & 375,000 & 1800 & 450,000 & & \\
\hline & $\mathrm{P}$ & 5694 & 10 & 56,940 & 70 & 398,580 & & \\
\hline & $\mathbf{T}$ & 5944 & & 431940 & & 848,580 & 416640 & 49.1 \\
\hline \multirow[t]{4}{*}{ 11) } & 2001 & & & & & & & \\
\hline & $\mathrm{M}$ & 300 & 1500 & 450,000 & 1800 & 540000 & & \\
\hline & $\mathrm{P}$ & 5992 & 10 & 59920 & 80 & 479360 & & \\
\hline & $T$ & 6292 & & 509920 & & 1019360 & 509440 & 49.98 \\
\hline \multirow[t]{4}{*}{ 12) } & 2002 & & & & & & & \\
\hline & $\mathrm{M}$ & 400 & 1800 & 720,000 & 2100 & 840000 & & \\
\hline & $\mathrm{P}$ & 6886 & 15 & 103,290 & 120 & 826320 & & \\
\hline & $T$ & 7286 & & 823290 & & 1666320 & 843030 & 50.59 \\
\hline
\end{tabular}




\begin{tabular}{|c|c|c|c|c|c|c|c|c|}
\hline 13) & 2003 & & & & & & & \\
\hline & $\mathrm{M}$ & 448 & 1800 & 806400 & 2100 & 940800 & & \\
\hline & $\mathrm{P}$ & 6990 & 15 & 104850 & 120 & 838800 & & \\
\hline & $T$ & 4738 & & 911250 & & 1779600 & 868350 & 48.79 \\
\hline \multirow[t]{4}{*}{ 14) } & 2004 & & & & & & & \\
\hline & $\mathrm{M}$ & 460 & 1800 & 828,000 & 2100 & 966000 & & \\
\hline & $\mathrm{P}$ & 7020 & 15 & 105300 & 120 & 842400 & & \\
\hline & $T$ & 7480 & & 933300 & & 1808400 & 875100 & 48.39 \\
\hline \multirow[t]{4}{*}{ 15) } & 2005 & & & & & & & \\
\hline & $\mathrm{M}$ & 475 & 1800 & 855000 & 2100 & 997500 & & \\
\hline & $\mathrm{P}$ & 7026 & 15 & 105390 & 120 & 843120 & & \\
\hline & $T$ & 7991 & & 960390 & & 1840620 & & \\
\hline \multirow[t]{4}{*}{ 16) } & 2006 & & & & & & & \\
\hline & $\mathrm{M}$ & 488 & 1800 & 878400 & 2100 & 940800 & & \\
\hline & $\mathrm{P}$ & 7050 & 15 & 105750 & 120 & 846000 & & \\
\hline & $T$ & 7538 & & 984150 & & 1786800 & 880230 & 49.26 \\
\hline \multirow[t]{4}{*}{ 17) } & 2007 & & & & & & & \\
\hline & $\mathrm{M}$ & 500 & 1800 & 900000 & 2100 & 1050000 & & \\
\hline & $\mathrm{P}$ & 7061 & 15 & 105915 & 120 & 847320 & & \\
\hline & $T$ & 7561 & & 1005915 & & 1897320 & 891405 & 46.98 \\
\hline \multirow[t]{4}{*}{ 18) } & 2008 & & & & & & & \\
\hline & M & 508 & 1800 & 914400 & 2300 & 1168400 & & \\
\hline & $\mathrm{P}$ & 7100 & 15 & 106500 & 150 & 1065000 & & \\
\hline & $T$ & 7608 & & 1020900 & & 2233400 & 1212500 & 54.29 \\
\hline \multirow[t]{4}{*}{ 19) } & 2009 & & & & & & & \\
\hline & $\mathrm{M}$ & 522 & 1800 & 939600 & 2300 & 1200600 & & \\
\hline & $\mathrm{P}$ & 7115 & 15 & 106725 & 150 & 1067250 & & \\
\hline & $T$ & 7637 & & 1046325 & & 2267850 & 1221525 & 53.86 \\
\hline \multirow[t]{4}{*}{ 20) } & 2010 & & & & & & & \\
\hline & $\mathrm{M}$ & 560 & 1800 & 1008000 & 2300 & 1288000 & & \\
\hline & $\mathrm{P}$ & 7260 & 15 & 108900 & 150 & 1089000 & & \\
\hline & $T$ & 7820 & & 1116900 & & 2377000 & 1260100 & 53.01 \\
\hline \multirow[t]{4}{*}{ 21) } & 2011 & & & & & & & \\
\hline & M & 490 & 1800 & 882000 & 2300 & 1127000 & & \\
\hline & $\mathrm{P}$ & 7010 & 15 & 105150 & 150 & 1051500 & & \\
\hline & $T$ & 7500 & & 987150 & & 2178500 & 1191350 & 54.69 \\
\hline
\end{tabular}

Sources: Authors field report (2011)

It has been released in this study that with the depletion of mangrove forest ecosystem, there has been a lot of occupational drifts in the area. Generally, the mangrove ecosystem has been utilized in various forms such as for fuelwood, hunting, farming and fishing. In table 6, it was discussed that out of 137 sampled population involved in fuelwood collection and logging, 82 (representing 60\%) are now disengaged from fuelwood gathering and logging. Observations from the field revealed that most of these people engaged in these activities are migrants from neighbouring states and local government areas. With the retreat of the mangrove forest ecosystem, they have all returned to their place of origin to be involved in all forms of jobs or the other. It was also realized that Mbukpa/Akan Orok area has the highest number of this disengaged gatherers/loggers 
Table 4: Depletion rate of Mangrove Forest Ecosystem over Time (1991-2011)

\begin{tabular}{|c|c|c|c|c|c|c|c|c|c|}
\hline $\begin{array}{l}\text { Cover } \\
\text { types }\end{array}$ & $\begin{array}{c}\text { Cove } \\
\text { r } \\
\text { statu } \\
\text { s } \\
1970 \\
\left(\mathrm{Km}^{2}\right. \\
\quad) \\
\end{array}$ & $\begin{array}{c}\text { Cove } \\
\text { r } \\
\text { statu } \\
\text { s } \\
1991\end{array}$ & $\begin{array}{c}\text { Area } \\
\text { chang } \\
\mathrm{e} \\
1970- \\
1991 \\
\left(\mathrm{Km}^{2}\right)\end{array}$ & $\begin{array}{c}\text { Rate of } \\
\text { change( } \\
\text { area } \\
\text { change } \\
\div \text { No.of } \\
\text { yrs) } \\
\left(\mathrm{Km}^{2}\right) \\
\end{array}$ & $\begin{array}{l}\text { Area } \\
\text { chang } \\
\text { e }(\%)\end{array}$ & $\begin{array}{c}\text { Cove } \\
\text { r } \\
\text { statu } \\
\text { s } \\
2011 \\
\left(\mathrm{Km}^{2}\right. \\
\quad) \\
\end{array}$ & $\begin{array}{c}\begin{array}{c}\text { Area } \\
\text { chang }\end{array} \\
\text { e } 1991- \\
2011 \\
\mathrm{Km}^{2}\end{array}$ & $\begin{array}{c}\text { Rate } \\
\text { of } \\
\text { chang } \\
\text { e per } \\
\text { year } \\
(1991- \\
2011) \\
\end{array}$ & $\begin{array}{c}\text { Area } \\
\text { Chang } \\
\text { e } \\
(\%)\end{array}$ \\
\hline $\begin{array}{c}\text { Mangrove } \\
\mathrm{s}\end{array}$ & 72.69 & 69.94 & -2.75 & 0.145 & 2.66 & 37.82 & -32.12 & 1.691 & 31.12 \\
\hline $\begin{array}{l}\text { Nypa } \\
\text { Palm }\end{array}$ & 18.27 & 21.31 & 3.04 & 0.16 & 2.95 & 53.57 & 32.26 & 1.70 & 31.26 \\
\hline $\begin{array}{c}\text { Fresh } \\
\text { water } \\
\text { swamp }\end{array}$ & 4.96 & 3.85 & -1.11 & 0.06 & 1.08 & 3.79 & -0.06 & 0.003 & 0.06 \\
\hline $\begin{array}{l}\text { Farm } \\
\text { Land }\end{array}$ & 0.7 & 1.00 & 0.3 & 0.02 & 0.29 & 3.22 & 2.22 & 0.12 & 2.15 \\
\hline $\begin{array}{l}\text { Raphia } \\
\text { palm }\end{array}$ & 1.0 & 1.01 & 0.01 & 0.001 & 0.01 & 1.04 & 0.03 & 0.002 & 0.03 \\
\hline Built up & $5 . .59$ & 6.10 & 0.51 & 0.027 & 0.49 & 8.77 & 2.67 & 0.14 & 2.59 \\
\hline
\end{tabular}

Source: Author's Field Report (2011)

The Olumber Olumber Obu church located in this area has attracted so many worshipers from far and near who took to fuelwood gathering as a means of sustenance to complement their church activities. Hence, with the downturn in fuelwood business due to depletion of the mangrove ecosystem, many of these worshipers cum fuelwood business people returned to the church while others who could not contend with the situation returned to their homes. Duketown has the least number of disengaged loggers $(4.9 \%)$ primarily because most of the people here are civil servants and only a negligible few are involved in logging, essentially migrants.

In table 7, 10 respondents (representing $58.8 \%$ ) of the sampled population of 17 involved in hunting were disengaged from hunting. Hunting generally requires thickets of bushes or forests where these animals usually take abode. But with the devastation of the mangrove ecosystem, most of the animals also migrate thereby making them unavailable for the hunters. In this regard, the hunters are automatically thrown out of their jobs.

Table 8, revealed that 40 respondents (representing 60\%) of the population who are engaged in fishing (68) were disengaged. Observations in the field revealed that as the mangrove ecosystem was being opened up, it affected catches because most species of fishes were migrating to the sea. This invariably means that fishing was now restricted to the high sea which may be costly. This may have resulted in many people abandoning the business. 
Finally, table 9 indicated that 69 respondents $(57 \%)$ of the total sampled population of 121 involved in farming were now disengaged. It should be noted that the depletion of the mangrove ecosystem in the area gave rise to the growth of Nypa palm as seen in table. This palm dominated the area to the level that farming can no longer be tenable. The resultant effect is that farmers had to abandon their farmland for other jobs.

Table 5: Average No. of Persons Disengaged from Mangrove Fuelwood Harvesting/Logging

\begin{tabular}{|c|c|c|c|c|c|}
\hline S/NO & Communities & $\begin{array}{l}\text { Total } \\
\text { population } \\
\text { sampled per } \\
\text { community. }\end{array}$ & $\begin{array}{l}\text { No.of } \\
\text { persons } \\
\text { involved in } \\
\text { fuelwood } \\
\text { harvesting }\end{array}$ & $\begin{array}{l}\text { No.of } \\
\text { persons } \\
\text { disengaged } \\
\text { from } \\
\text { fuelwood } \\
\text { harvesting }\end{array}$ & $\begin{array}{c}\text { Percentage } \\
(\%)\end{array}$ \\
\hline 1 & Anantigha & 120 & 30 & 18 & 22 \\
\hline 2 & Duketown & 79 & 8 & 4 & 4.9 \\
\hline 3 & Efit-Obuya & 34 & 13 & 8 & 9.6 \\
\hline 4 & $\begin{array}{l}\text { Henshew/Edibe- } \\
\text { Edibe }\end{array}$ & 22 & 20 & 12 & 4.6 \\
\hline 5 & $\begin{array}{l}\text { Mbukpa/Akan } \\
\text { Esuk Orok }\end{array}$ & 145 & 66 & 40 & 48.0 \\
\hline Total & & 400 & 137 & 82 & 100 \\
\hline
\end{tabular}

Source: authors field survey 2011

Table 6: No. of persons Disengaged from Hunting.

\begin{tabular}{|l|l|c|c|c|c|}
\hline S/NO & Communities & $\begin{array}{l}\text { Total } \\
\text { population } \\
\text { sampled. }\end{array}$ & $\begin{array}{l}\text { No.of persons } \\
\text { involved in } \\
\text { Hunting }\end{array}$ & $\begin{array}{l}\text { No.of persons } \\
\text { disengaged } \\
\text { from Hunting }\end{array}$ & $\begin{array}{l}\text { Percenta } \\
\text { ge } \\
\text { (\%) }\end{array}$ \\
\hline 1 & Anantigha & 120 & 34 & 2 & 20 \\
\hline 2 & Duketown & 79 & 2 & 1 & 10 \\
\hline 3 & Efit-Obuya & 22 & 3 & 2 & 20 \\
\hline 4 & $\begin{array}{l}\text { Henshew/Edibe- } \\
\text { Edibe }\end{array}$ & 34 & 2 & 1 & 10 \\
\hline 5 & $\begin{array}{l}\text { Mbukpa/Akan } \\
\text { Esuk Orok }\end{array}$ & 145 & 6 & 4 & 40 \\
\hline Total & & $\mathbf{4 0 0}$ & $\mathbf{1 7}$ & $\mathbf{1 0}$ & $\mathbf{1 0 0}$ \\
\hline
\end{tabular}

Source: authors field survey 2011 
Table 7: No. of persons Disengaged from Fishing

\begin{tabular}{|l|l|c|c|c|c|}
\hline S/NO & Communities & $\begin{array}{l}\text { Total } \\
\text { population } \\
\text { sampled per } \\
\text { Community. }\end{array}$ & $\begin{array}{l}\text { No.of } \\
\text { persons } \\
\text { involved in } \\
\text { Fishing }\end{array}$ & $\begin{array}{l}\text { No.of } \\
\text { persons } \\
\text { disengaged } \\
\text { from Fishing }\end{array}$ & $\begin{array}{l}\text { Percentage } \\
\mathbf{( \% )}\end{array}$ \\
\hline 1 & Anantigha & 120 & 24 & 16 & 40 \\
\hline 2 & Duketown & 79 & 4 & 2 & 5 \\
\hline 3 & Efit-Obuya & 22 & 33 & 18 & 45 \\
\hline 4 & $\begin{array}{l}\text { Henshew/Edibe- } \\
\text { Edibe }\end{array}$ & 34 & 7 & 4 & 10 \\
\hline 5 & $\begin{array}{l}\text { Mbukpa/Akan } \\
\text { Esuk Orok }\end{array}$ & 145 & 0 & 0 & 0 \\
\hline Total & & $\mathbf{4 0 0}$ & $\mathbf{6 8}$ & $\mathbf{4 0}$ & $\mathbf{1 0 0}$ \\
\hline
\end{tabular}

Source: authors field survey 2011

Table 8: No. of persons Disengaged from Farming

\begin{tabular}{|l|l|c|c|c|c|}
\hline S/NO & Communities & $\begin{array}{l}\text { Total sampled } \\
\text { population. }\end{array}$ & $\begin{array}{l}\text { No.of } \\
\text { persons } \\
\text { involved in } \\
\text { Farming }\end{array}$ & $\begin{array}{l}\text { No.of } \\
\text { persons } \\
\text { disengaged } \\
\text { from } \\
\text { Farming }\end{array}$ & $\begin{array}{l}\text { Percentage } \\
\mathbf{( \% )}\end{array}$ \\
\hline 1 & Anantigha & 120 & 42 & 24 & 35.0 \\
\hline 2 & Duketown & 79 & 10 & 5 & 7.2 \\
\hline 3 & Efit-Obuya & 22 & 11 & 8 & 12.0 \\
\hline 4 & $\begin{array}{l}\text { Henshew/Edibe- } \\
\text { Edibe }\end{array}$ & 34 & 8 & 4 & 5.8 \\
\hline 5 & $\begin{array}{l}\text { Mbukpa/Akan } \\
\text { Esuk Orok }\end{array}$ & 145 & 50 & 28 & 40.00 \\
\hline Total & & $\mathbf{4 0 0}$ & $\mathbf{1 2 1}$ & $\mathbf{6 9}$ & $\mathbf{1 0 0}$ \\
\hline
\end{tabular}

Source: Authors field survey 2011

\section{Conclusion}

Mangrove ecosystem destabilization in the coastal communities of Calabar South, Local Government Area of Cross River State has been increasing rapidly over the years. Although majority of the people of the area shows great dependence on the exploitation of mangrove as a means of livelihood, the deleterious effect of the mangrove depletion on human beings and the environment remained unnoticed. The prevalence of floods, coastal erosion and in recent times changes in occupation of the people are clear manifestation of overexploitation of the mangrove ecosystem. Word still, the invasion of the nypa palm gradually replacing mangrove has led to habitat alteration and the reduction in fish productivity. Little wonder, most of the habitants of the area now travel as far as Bakassi and Itu to get their daily catch of fish to supplement their needs. In 
sum mangrove exploitation in this area will continue unabated as long as there is generally lack of forest management plan as well as non enforced regulatory and monitoring mechanisms to carry out effective mangrove regeneration and conservation programme in the area.

\section{References}

Chan, H. T. (1986). Human Habitatation and traditional uses of the mangrove ecosystem in peninsular Malaysia. Man in the mangroves (ed). Kunstadter, P. et al, the United Nations University, Tokyo.

Mantra, I. B. (1986)). Socio-economic problems of the Kampong laut community in central Java edited workshop paper on the socio-economic situation of human settlements in mangrove forests under the auspices of United Nations University (UNU) and the National Research Council of Thailand: http://localhost/cgibin/gw?e $=$ elc10home.

Meteorological service (1980). Soil-vegetation interrelationships of mangrove published by Geoderma, an international journal of soil science Geoderma 64 (1994) 167181.

NRC (2001). Natural Resources Conservation Service.

Molles. M C (1999) Ecology, Concepts and Application. McGrew-Hill, New York, pp. 63-67.

htt:/www.yahoo.com/Services/Ecology/Ecosystems/Estuaries.

Quarto, A. (2001). Analysis of mangrove resources; Mangrove Action Project, Mangrove Quarterly Report, UAS.

Russell, H. (1986). Mangroves: The Forgotten Habitat in Jeremy Stafford-Deitsch (eds); Immel Publishing Limited, London Wix $5 \mathrm{AE}$

Ukpong I. E. (2009), Perspective on Environmental Management. Env. Systems Club Uyo pp. 24.

Ukpong, I. E. (2007). Mangrove Forest Under Threat. An Evaluation of the Integrity of Mangrove Ecosystem Functioning; The 17th Inaugural Lecture Delivered in the University of Uyo, $1^{\text {st }}$ March 2007.

Ukpong, I. E. (1995). Mangrove Soils of the Creek Town, Calabar River Swamp, South Easterm Nigeria, Journal of International Society for Tropical Ecology 36 (1): 103-115. 
